\title{
Assigning Common Law Claims for Fraud
}

\author{
Teal E. Luthy†
}

A man buys a membership in a beach club. The salesman who sells him the membership states that the company will build a clubhouse building to certain specifications. The sale, however, is a scam, and the clubhouse "building" turns out to be a hut. The membership is virtually without value. The man wants to sue. ${ }^{1}$

He consults an attorney, who investigates his case and informs him that he probably has a winning common law tort claim of deceit for fraud. ${ }^{2}$ In the attorney's estimation, however, the claim is not worth enough to take on a contingency fee basis. Realizing that if he pays the attorney on an hourly basis he will not recover enough to make pursuing the claim worthwhile, the man considers contacting other people who purchased memberships in the club and offering to pay them to assign their claims to him. He calculates that, if he purchases enough claims, the potential damage award will be large enough to make his investment in the case worthwhile.

It is not clear, however, whether the law permits other victims of this beach club fraud to assign-essentially to sell-their claims to the would-be plaintiff. Nor is it clear whether a third party, an individual who had never owned a membership in the beach club, could purchase the claims. While fourteen states do not limit the assignment of common law claims for fraud, seven states forbid such assignments. The remaining states lack a bright line rule; their courts often determine the validity of an as-

$\dagger$ B.A. 1991, Cornell University; J.D. Candidate 1999, The University of Chicago.

1 The scenario loosely is based on a 1933 California case, Jackson $v$ Deauville Holding Co, $219 \mathrm{Cal} 498,27 \mathrm{P} 2 \mathrm{~d} 643,643-44$ (1933) (holding that the claims for fraud at issue were assignable).

2 The elements of common law fraud are as follows: the defendant made a representation as to a material fact or concealment of a material fact; the representation was false and known by the defendant to be false; the defendant intended to deceive the plaintiff and to induce the plaintiff to act upon the representation; the plaintiff justifiably relied on the representation; and the plaintiff suffered an injury as a result of the reliance. See $J u$ man v Louise Wise Services, 174 Misc 2d 49, 663 NYS2d 483, 488 (NY Sup Ct 1997); Next Day Motor Freight, Inc v Hirst, 950 SW2d 676, 679 (Mo App 1997); Russ v TRW, Inc, 59 Ohio St 3d 42, 570 NE2d 1076, 1083 (1991); Gonsalves $v$ Hodgson, 38 Cal 2d 91, 237 P2d 656,662 (1951). Some states consider recklessness enough to satisfy the intent element. See Juman, 663 NYS2d at 488; T.O. Stanley Boot Co v Bank of El Paso, 847 SW2d 218, 222 (Tex 1992). 
signment by reference to the "nature" of the claim assigned: property claims are assignable, personal claims are not.

The statutes that forbid assignment of fraud claims, and to a lesser degree the courts that do the same, rely on the premise that free assignability will increase the number of fraud claims and cause harm to victims of fraud. For instance, in Southern Farm Bureau Casualty Insurance Co $v$ Wright Oil $\mathrm{Co}^{3}{ }^{3}$ the court explained that "[i]f causes of action for personal injuries could be assigned, then speculators could buy up such claims, perhaps at necessitous discounts, and conduct a profitable traffic in human pain and suffering. ${ }^{\text {"4 }}$

This objection is wrongheaded. Courts wary of free assignability incorrectly assess the consequences of assignability. An active trade for fraud claims would not lead to widespread abuse of fraud victims; instead, by increasing the likelihood that the victims would receive some compensation for their injuries, it would leave them better off. Moreover, such a trade would deter fraud by increasing the likelihood that perpetrators of fraud would be taken to court. Fraud is a difficult claim to prove, and there is little concern that deterring common law fraud will chill desirable behavior. ${ }^{5}$ Accordingly, a rule promoting additional deterrence is desirable.

Part I of this Comment describes the assignability rules applied in the different states. Part II explores the advantages and disadvantages of three different approaches to assignability and argues that courts should abandon all prohibitions on assigning common law fraud claims. Part III discusses the impediments that prevent the present development of a deep market for fraud claims and argues that these prohibitions serve the interests of lawyers and defendants at the expense of fraud victims.

\section{CURRENT APPROACHES TO ASSIGNABILITY}

\section{A. Assignability of Choses in Action}

Early common law strictly banned the assignment of all "choses in action" - rights to bring action to take possession of

3248 Ark 803, 454 SW2d 69 (1970).

- Id at 70.

- See Daniel R. Fischel and Alan O. Sykes, Civil RICO After Reves: An Economic Commentary, 1993 Sup Ct Rev 157, 177-78 (noting that common law fraud is strictly unproductive and therefore an attractive suit for high damages).

${ }^{\circ}$ See Tiernan $v$ Jackson, 30 US (5 Pet) 580, 597 (1831) (stating that the general principle of law is that choses in action are not assignable); Picadilly, Inc $v$ Raikos, 582 NE2d 338, 339 (Ind 1991) (noting the historical fact of nonassignability); Harold R. Weinberg, Tort Claims as Intangible Property: An Exploration from an Assignee's Perspective, $64 \mathrm{Ky}$ 
property. ${ }^{7}$ Courts have offered several explanations to support this historical bar. ${ }^{8}$ Some contend that the common law prohibition against champerty and maintenance demanded a corresponding ban on assignment. ${ }^{9}$ Others argue that because a chose in action presupposes a personal relationship between the parties, ${ }^{10}$ or because it is a mere "expectancy" it cannot be transferred to another person.

In modern times, many states have reversed the common law rule at least in part, and the trend is toward permitting the assignment of all choses in action. ${ }^{12}$ Today, every state permits the assignment of causes of action sounding in contract. ${ }^{13}$ In addition, a few states have enacted statutes that explicitly provide for assignability of tort claims as well. ${ }^{14}$ In the absence of such a statute, many courts now determine the assignability of tort claims

L J 49, 51-52 (1975) (recording that ancient English law permitted no assigning).

7 Black's Law Dictionary 241 (West 6th ed 1990).

- See Martin v Morgan Drive Away, 665 F2d 598, 603 n 3 (5th Cir 1982) (describing debate over historical reasons for bar on assignment). Some courts distinguish between assignment of a claim and assignment of the proceeds from a claim. See, for example, Kuhns v Standard Oil Co of California, Western Operations, 257 Or 482, 478 P2d 396, 405 (1970). This Comment discusses assigning causes of action rather than proceeds from judgment.

- Champerty is "[a] bargain between a stranger and a party to a lawsuit by which the stranger pursues the party's claim in consideration of receiving part of any judgment proceeds." Black's Law Dictionary at 231. Maintenance is "officious intermeddling in a lawsuit by a non-party by maintaining, supporting or assisting either party, with money or otherwise, to prosecute or defend the litigation." Id at 954. See Martin, 665 F2d at 603.

Fear that free assignment would lead to champerty and maintenance is the reason commentators cite most frequently to explain the early common law bar on assignment. See Lampet's Case, 10 Coke 46b, 48a, 77 Eng Rep 994, 997 (KB 1603) (noting "the great wisdom and policy of the sages and founders of our law, who have provided, that no possibility, [ ] right, title, nor thing in action shall be granted or assigned to strangers, for that would be the occasion of multiplying of contentions and suits, of great oppression of the people ... and the subversion of the due and equal execution of justicen); Samuel Williston, 14 Williston on Contracts $\$ 1715$ at 872 (Lawyers Co-op 3d ed 1972) ("Public policy opposes trafficking in lawsuits. The early common law was very reluctant to permit the assignment of rights of action. Objection was indeed raised on the ground of maintenance to the assignment of any choses of action."); Samuel Williston, 3 Williston on Contracts $\S 405$ at 7-8 (Baker, Voorhis 3d ed 1960); W.S. Holdsworth, 7 A History of English Law 531-32 (Little, Brown 1926) (saying that the prevention of maintenance came to be the only reason for nonassignability).

${ }^{10}$ See, for example, J.B. Ames, The Disseisin of Chattels: Inalienability of Choses in Action, 3 Harv L Rev 337, 339 (1890) ("[A] chose in action always presupposes a personal relation between two individuals. But a personal relation in the very nature of things cannot be assigned.").

"See Rice $v$ Stone, 83 Mass (1 Allen) 566, 569 (1861) (reasoning that one cannot assign "that which he has not").

${ }^{12}$ See Williston, 14 Williston on Contracts at $\$ 1715$.

${ }^{13}$ See Weinberg, $64 \mathrm{Ky} \mathrm{L} J$ at 53-54 (cited in note 6) (describing the development of assignability of contract causes of action).

" See, for example, Tex Prop Code Ann $\$ 12.014$ (Vernon 1984). 
by looking to survival rules-the rules that govern whether a claim survives the death of the claimant.

The relationship between survivability and assignability apparently originated with dictum in Comegys $v$ Vasse, ${ }^{15}$ an 1828 Supreme Court opinion: ${ }^{16}$

In general, it may be affirmed, that mere personal torts, which die with the party, and do not survive to his personal representative, are not capable of passing by assignment; and that vested rights $a d$ rem and in re, possibilities coupled with an interest, and claims growing out of, and adhering to property, may pass by assignment. ${ }^{17}$

This dictum posits a seemingly simple equivalency between survivability and assignability: if a cause of action survives the death of the victim, the victim may assign it. The matter is complicated, however, because survival rules vary considerably among the states. ${ }^{18}$ In general, when the statute fails to specify a rule for a particular claim, courts follow the broad principles articulated in Comegys: personal injury claims do not survive and are not assignable, but claims arising out of property interests do survive and are assignable. ${ }^{19}$ On occasion, however, courts reject the equivalency between survivability and assignability and hold a claim unassignable on public policy grounds, ${ }^{20}$ even though a survival statute provides for survival of the claim. ${ }^{21}$

${ }^{15} 26$ US 193 (1828).

${ }^{18}$ See Weinberg, $64 \mathrm{Ky} \mathrm{L} \mathrm{J} \mathrm{at} 62$ (cited in note 6) (attributing the origins of the relationship to Comegys).

${ }^{17}$ Comegys, 26 US at 213.

${ }^{18}$ See Melville M. Bigelow, 1 A Treatise on the Law of Fraud 213 (Little, Brown 1888) ("By the rules of the common law, actions for damages caused by fraud do not survive to the representative of the injured party. Whether such actions will survive must therefore be a question of statute; and the statutes vary considerably.").

${ }_{19}$ See, for example, Barnes Coal Corp v Retail Coal Merchants Association, 128 F2d 645, 649 (4th Cir 1942) (holding that Virginia common law rules of survival distinguish personal injury claims from property claims).

${ }^{20}$ See Jackson v Rogers \& Wells, 210 Cal App 3d 336, 258 Cal Rptr 454, 461-62 (1989) (holding that bare right to sue for fraud is not assignable as against public policy); Harleysville Mutual Insurance Co v Lea, 2 Ariz App 538, 410 P2d 495, 499 (1966) (noting that nonassignability rule has much support in public policy); North Chicago Street Railroad Co $v$ Ackley, 171 Ill 100, 49 NE 222, 224-26 (1897) (holding that while a personal injury action survived by virtue of the survival statute, it was nevertheless not assignable on public policy grounds). See also 1989 NY Gen Oblig Laws § 13-101 (prohibiting all transfers that "would contravene public policy"); Joseph Story, 2 Commentaries on Equity Jurisprudence $\$ 1040 \mathrm{~h}$ (Little, Brown 10th ed 1870) ( bill in equity for a fraud, committed on the assignor, will be held void, as contrary to public policy."). But see Croxton v Crowley Maritime Corp, 758 P2d 97, 99 (Alaska 1988) (considering public policy in upholding the assignability of personal injury claim).

${ }^{21}$ For example, Florida has a survival statute, 2 Fla Stat Ann \& 46.021 (West 1994), but Florida's courts have held that the survivability of a tort claim does not determine 


\section{B. Assignability of Common Law Fraud Claims}

States take three basic approaches to the assignability of fraud claims: (1) no fraud claims are assignable; (2) all fraud claims are assignable; and (3) the assignability of a fraud claim depends on its nature-those fraud claims arising out of property interests are assignable, but those arising out of personal injuries are not. Within this last category, states use a variety of approaches in determining whether a fraud claim is personal or arises out of a property interest. The following Table indicates which states adopt each of the various approaches and identifies and categorizes the remaining states, which lack controlling precedents on the issue of assigning fraud. ${ }^{22}$

\begin{tabular}{|l|l|c|}
\hline \multicolumn{1}{|c|}{ Rule } & \multicolumn{1}{|c|}{ States Following Rule } & Total \\
\hline $\begin{array}{l}\text { All fraud claims can be as- } \\
\text { signed }\end{array}$ & $\begin{array}{l}\text { Colorado; Ilinois; Iowa; Mary- } \\
\text { land; Michigan; Minnesota; Mis- } \\
\text { sissippi; Nebraska; New York; } \\
\text { South Dakota; Texas; West Vir- } \\
\text { ginia; Wisconsin; Wyoming }\end{array}$ & 14 \\
\hline $\begin{array}{l}\text { No fraud claims can be as- } \\
\text { signed }\end{array}$ & $\begin{array}{l}\text { Georgia; Kansas; Massachusetts; } \\
\text { Nevada; New Jersey; Oklahoma; } \\
\text { Vermont }\end{array}$ & 7 \\
\hline $\begin{array}{l}\text { Assignability of fraud claim } \\
\text { depends on whether it } \\
\text { arises out of a personal in- } \\
\text { jury or an injury to property }\end{array}$ & $\begin{array}{l}\text { Alabama; California; Connecti- } \\
\text { cut; Florida; Idaho; Missouri; } \\
\text { North Dakota; North Carolina; }\end{array}$ & 11 \\
\hline $\begin{array}{l}\text { Assignability probably de- } \\
\text { pends on nature of claim; no } \\
\text { precedent on fraud, but as- } \\
\text { signability of tort claims } \\
\text { generally turns on per- } \\
\text { sonal/property distinction }\end{array}$ & $\begin{array}{l}\text { Arizona; Arkansas; Hawaii; Indi- } \\
\text { ana; Kentucky; Louisiana; Maine; } \\
\text { Montana; New Hampshire; New } \\
\text { land; Tennessee }\end{array}$ & 13 \\
\hline
\end{tabular}

whether it is assignable. See Notarian v Plantation AMC Jeep, Inc, 567 S2d 1034, 1035 (Fla Dist Ct App 1990) (explaining that even though Florida has a survival statute, Florida's courts follow the common law prohibition on assignability of personal injury claims). See also Southern Farm Bureau, 454 SW2d at 71 (stating that "whenever courts have explored the policy considerations pertinent to the issue, they have held-without exception, we think - that survivability of personal injury claims does not attract assignability in its wake"); Harleysuille Mutual, 410 P2d at 498 (noting that survivability and assignability are not subject to the same policy concerns); Picadilly 582 NE2d at 341 ("Today, it seems anachranistic to resolve the issue of the assignability of a . . claim by deciding whether such a claim would survive the client's death."); Weinberg, $64 \mathrm{Ky} \mathrm{L} J$ at $69-78$ (cited in note 6) (criticizing the equivalency on the ground that a decedent's personal representative has interests different from an assignee of a living assignor).

2 The Appendix compiles cases from each state. 


\begin{tabular}{|c|c|c|}
\hline $\begin{array}{l}\text { Fraud claims are probably } \\
\text { assignable; no precedent on } \\
\text { fraud, but assignability of } \\
\text { claims depends on survival } \\
\text { and survival statute ap- } \\
\text { pears to provide for survival } \\
\text { of claims for fraud and de- } \\
\text { ceit }\end{array}$ & $\begin{array}{l}\text { Alaska; Delaware; Ohio; Oregon; } \\
\text { South Carolina }\end{array}$ & 5 \\
\hline
\end{tabular}

Courts have sorted themselves into the categories in the Table using two primary methods: (1) determining amenability to assignment by referring to survival rules and (2) ignoring survival rules and looking to public policy justifications for and against assignment. The first method is followed by a great majority of the courts. These courts recognize the general common law equivalency between the survival of choses of action and their amenability to assignment. Hence, they turn to survival statutes and common law survival rules to determine the assignability of fraud claims.

Some survival statutes clearly specify that fraud and deceit actions survive. ${ }^{23}$ Others explicitly provide that all causes of action survive. ${ }^{24}$ In either case, where a court is looking to survival rules, these statutes provide them with a straightforward rule of decision.

Many survival statutes, however, do not provide such clear guidance. Where the survival statutes do not provide clear guidance, courts are forced back to the common law to determine survivability. Accordingly, they must consider the nature of the fraud claim, ${ }^{25}$ because under the common law only claims for injuries to property survived; claims for personal injuries did not. ${ }^{26}$

Unfortunately, fraud claims do not fit neatly into either the personal injury or the injury to property category, and courts disagree about the nature of fraud claims. At one extreme, a few courts refuse to characterize any fraud claim as a property-based claim, reasoning that claims for fraud-even when property rights are involved-arise out of the harm to the personal right to

${ }^{23}$ See, for example, Neb Rev Stat \$ 25-1401 (1995).

${ }^{24}$ See, for example, SD Cod Laws \& 15-4-1 (1984).

${ }^{25}$ See, for example, Nichols $v$ United States Fidelity and Guaranty Co, 37 Wis 2d 238, 155 NW2d 104, 107-09 (1967) (considering whether fraud survives if a survival statute does not mention it).

${ }^{2}$ See text accompanying note 19. See also Rowe $v$ United States Fidelity and Guaranty Co, 421 F2d 937, 940 (4th Cir 1970) (explaining that causes of action for wrongs done to real or personal property survive, whereas causes of action for wrongs done to person or reputation, or any purely personal wrong, do not survive). 
make a choice unhampered by fraudulent interference. ${ }^{27}$ Most courts, however, distinguish among fraud claims. These courts permit the assignment of claims attached to property rights (such as claims based on fraudulent sale of stock), ${ }^{28}$ but refuse to recognize assignments of personal claims (such as a claim arising out of an insurance contract).

Courts adhering to the personal/property distinction differ in where they draw the line between personal injuries and injuries to property. ${ }^{29}$ Some courts use the term personal injury to refer to all injuries, physical and intangible, to the personhood of the victim (as distinct from injuries to property). These courts consider many fraud claims-even claims arising out of contract-like relationships-to be personal and unassignable. ${ }^{30}$ Other courts use the term personal injury as a proxy for any claim for fraud transferred without a corresponding transfer of the underlying property rights (a "naked" claim for fraud). ${ }^{31}$

The second method courts have used to determine amenability to assignment is to ignore the survivability/assignability link and instead to declare that assignment of any fraud claim, or of any tort claim (including fraud), is contrary to public policy and

${ }^{27}$ See Generali-US Branch v Southeastern Security Insurance Co, 229 Ga App 277, 493 SE2d 731, 735 (1997); National Shawmut Bank of Boston $v$ Johnson, 317 Mass 485, 58 NE2d 849, 851 (1945); Phillips $v$ Malone, 223 Ala 381, $136 \mathrm{~S} \mathrm{793,} 795$ (1931); Grabow $v$ Bergeth, 59 ND 214, 229 NW 282, 287 (1930); White v Texas Co, 59 Utah 180, 202 P 826, 829-30 (1921); Tufts $v$ Matthews, 10 F 609, 611 (D RI 1882). See also Case Note, TortsFraud Action Not Assignable to Trustee in Bankruptcy, 9 DePaul L Rev 303, 305 (1960) ("[F]raud and deceit ... . while often arising out of a loss or injury to tangible property of assignor, remain[ ], in essence, personal to the party deceived."); D.C.D., Note, Torts: Assignment of Cause of Action Ex Delicto: Fraud and Deceit: Cal. Civ. Code $\$ 954,22 \mathrm{Cal} \mathrm{L}$ Rev 456, 458 (1934) (arguing that an action for fraud is based on the right to make a choice unimpeded by fraudulent interference).

${ }^{23}$ See, for example, Goodley $v$ Wank and Wank, Inc, 62 Cal App 3d 389, 133 Cal Rptr $83,84-85$ (1976) (noting that California courts have held assignable claims relating to the fraudulent sale of stock, distinguishing bare right to complain of fraud from claim for money or property obtained by fraud). See also McLaughlin $v$ National Union Fire Insurance Co of Pittsburgh, 23 Cal App 4th 1132, 29 Cal Rptr 2d 559, 567 (1994) (finding that plaintiff's claims were assignable because they involved purportedly fraudulent behavior that led to economic consequences and thus entailed more than purely personal wrongs); Mayer $v$ Rankin, 91 Utah 193, 63 P2d 611, 616-17 (1936) ("While a mere naked right to recover for fraud is not assignable, still, by what we conceive to be the weight of authority and bottomed on sound legal principles, an assignment is upheld when it carries with it a subsisting substantial right to property independent of the right to sue for fraud.").

${ }^{2}$ See, for example, Generali-US, 493 SE2d at 735.

${ }^{30}$ See, for example, id (holding that action for fraud arising out of an insurance contract is a personal injury action); Property Exchange \& Sales, Inc $v$ Bozarth, 778 SW2d 1, 2 n 1 (Mo App 1989) (noting distinction).

${ }^{31}$ See, for example, Jackson v Deauville Holding Co, 219 Cal 498, 27 P2d 643, 645 (1933) (noting that assignors transferred "much more than a mere naked right of action for fraud and deceit," because they also transferred the right to recover sums of money paid to the defendant). 
therefore void. ${ }^{32}$ This second method is followed by a much smaller group of courts than the first method. These courts raise the following policy objections to assignability: (1) allowing assignment will increase litigiousness; ${ }^{33}$ (2) valuation of fraud claims is too speculative; ${ }^{34}$ (3) allowing assignment will lead to collusive behavior; ${ }^{35}$ and (4) some causes of action are too personal to transfer to a third party..$^{36}$ The next Part evaluates each of these policy objections in the context of the three approaches courts have taken to the assignability of fraud claims.

\section{REVIEWING THE THREE APPROACHES TO ASSIGNABILITY OF FRAUD CLAIMS}

Courts and commentators offer a variety of arguments for and against the assignability of fraud claims. First, those favoring a complete ban on the assignment of fraud claims reason that the ban will prevent claim speculators from fomenting litigation or preying upon fraud victims who are willing to sell their claims for less than the claims are worth. ${ }^{37}$ Second, those courts that distinguish among fraud claims justify prohibiting the assignment of fraud claims directed at the personhood of the victim on the basis that the legal system would undermine the right to be free from personal fraud if it were to allow these fraud claims to be traded. ${ }^{38}$ By contrast, two recently published articles, although

${ }^{32}$ See, for example, Costanzo $v$ Costanzo, 248 NJ Super 116, 590 A2d 268, 271 (1991) (holding that as a matter of public policy a tort claim cannot be assigned in New Jersey); National Shawmut Bank of Boston, 58 NE2d at 851 (same for Massachusetts).

${ }^{33}$ See W.S. Holdsworth, The History of the Treatment of Choses in Action by the Common Law, 33 Harv L Rev 997, 1006-07 (1920) (explaining that courts historically have been reluctant to permit assignment because of the risk that doing so might encourage corruption within the legal system). But see Kleinwort Benson North America, Inc $v$ Quantum Financial Services, Inc, 1998 Ill LEXIS 343, *16-18 (rejecting argument that assignment of fraud cause of action will increase litigation where assignee was involved in litigation prior to assignment).

${ }^{34}$ See Wittenauer $v$ Kaelin, $228 \mathrm{Ky} \mathrm{679,} 15$ SW2d 461, 462 (Ky App 1929) (noting that the law disfavors speculation in legal claims); Weinberg, $64 \mathrm{Ky} \mathrm{L} \mathrm{J}$ at 52 (cited in note 6).

${ }^{35}$ See Brown v State Farm Mutual Automobile Insurance Association, 1 Ill App 3d 47, 272 NE2d 261, 264 (1971) (rejecting, in the insurance context, argument that permitting assignment of claims may lead to collusion); Ronald Goldstein, Reforming the Residential Mortgage Foreclosure Process, 97 Comm L J 255, 268-69 (1992) ("[S]hould a market in tort claims develop, plaintiffs generally might exaggerate their claims when discussing the possibility of the assignment with the potential assignee, in order to encourage the assignee to buy the claim.").

${ }^{36}$ Hedlund Manufacturing Co, Inc $v$ Weiser, Stapler \& Spivak, $517 \mathrm{~Pa} 522,539$ A2d 357, 358-59 (1988) (disallowing assignment of personal injury claims because personal injuries involve rights of concern to the individual alone); Weinberg, $64 \mathrm{Ky} \mathrm{L} \mathrm{J}$ at 52-53 (cited in note 6).

${ }^{37}$ See notes 42, 60-61, and accompanying text.

${ }^{38}$ See Wittenauer, 15 SW2d at 462. 
not specifically addressing fraud, have concluded that a deep market ${ }^{39}$ in personal injury claims would increase compensation for tort victims, deter personal injury torts, and reduce agency costs associated with contingency fees and class actions. ${ }^{40}$

This Part describes the justifications offered for each of the three positions courts have taken on assignability and explores each position's advantages and disadvantages.

\section{A. A Rule Prohibiting All Assignment of Fraud Claims}

The most common explanation offered by courts and commentators for the early common law rule against assignment of choses in action is the desire to avoid champerty and maintenance. ${ }^{41}$ Courts that prohibit assignment of claims for fraud do so because of a similar concern: fear that assignees will increase the overall number of fraud claims filed. ${ }^{42}$ The force of this objection depends, of course, on the belief that an increase in litigation would be harmful. That belief, in turn, rests on a comparison of the benefits of fraud litigation to the costs.

The benefits of fraud litigation may be relatively high-or at least higher than the benefits of negligence actions. To see this, it is useful to consider why excessive negligence litigation is socially undesirable. Professor Shavell discussed the social benefits of negligence litigation in an article regarding fee allocation:

Suppose, for instance, that it is felt that the social benefits of [automobile accident] litigation are low-that the deterrent effect of tort liability is negligible (the primary determinants

30 The term "deep market" is used in this Comment to denote a market in which fraud claims are commonly sold to third parties unrelated to the circumstances of the fraud, as opposed to one in which sales only take place among common victims of a fraud.

${ }^{\text {to }}$ See Peter Charles Choharis, A Comprehensive Market Strategy for Tort Reform, 12 Yale J Reg 435, 443-46 (1995); Marc J. Shukaitis, A Market in Personal Injury Tort Claims, 16 J Legal Stud 329, 334-47 (1987). Fraud presents a particularly compelling case for free assignability. Increasing deterrence against fraud presents less risk of encouraging individuals to take inefficient (i.e., excessive) precautions than does increasing deterrence against negligence. Accordingly, a market for fraud claims is even more desirable than a market for negligence-based torts. Moreover, even if no active, national market for fraud claims were to develop, permitting the assignment of such claims would promote both deterrence of fraud and compensation for fraud victims by ensuring that claims end up with the parties most likely to pursue the claims vigorously.

${ }^{4}$ See Picadilly, 582 NE2d at 339-40 (describing the historical reasons for bar on assignments).

${ }^{42}$ See Karp v Speizer, 132 Ariz 599, 647 P2d 1197, 1199 (Ariz App 1982) (noting that assignment may encourage champerty and thereby implying that it would increase litigation); Southern Farm Bureau, 454 SW2d at 70 ("[T]he principal justification for the rule against assignability was the avoidance of . . . the fomenting of litigation between others."); Garford Motor Truck Co v Buckson, 34 Del 103, 143 A 410, 411 (Del Super Ct 1927) (reasoning that assignment encourages litigation). 
of driving behavior being criminal liability and the desire not to be injured); that the compensatory role of tort liability is limited (private and social insurance providing satisfactory alternative means of compensation); and that legal costs and public administrative expenses are significant. Then ... the actual volume of litigation could indeed be thought to exceed the desirable level. ${ }^{43}$

Several features of fraud actions distinguish them from negligence actions. These features make an increase in the number of fraud actions more desirable than an increase in the number of negligence actions. First, because fraud is an intentional tort, the deterrent effect of suits for fraud is higher than the deterrent effect of negligence suits. To illustrate, because fraud requires that the tortfeasor consciously intend to defraud the victim, potential fraud tortfeasors should be more readily deterred than potentially negligent automobile drivers. Liability arising out of an automobile accident requires no corresponding level of intentional action. A tortfeasor who intends to commit a tort is more able than a negligent tortfeasor to consider the likelihood of having to pay a judgment to his victim, precisely because he must intend his acts; they are within his control to a greater extent than are negligent acts. Accordingly, he is more likely to respond-by deciding not to commit the tort-to a significant increase in the odds that he will have to pay a judgment.

Similarly, we should not be concerned that an increased number of fraud actions will lead to overdeterrence. Because fraud involves "not a conflict between legitimate (productive) activities but a coerced transfer of wealth, ${ }^{344}$ there is little risk of chilling productive behavior by overdeterring fraud. Because we want to deter fraud absolutely, we need not worry about inducing cost-ineffective precautions. Additionally, unlike personal injuries, individuals do not generally insure against fraud, so the compensatory role of fraud actions is important. ${ }^{45}$ The high litigation costs associated with an increase in the volume of fraud cases are cause for concern. However, if a short-term increase in the number of fraud claims deters future fraud, the volume of

43 Steven Shavell, Suit, Settlement, and Trial: A Theoretical Analysis Under Alternative Methods for the Allocation of Legal Costs, $11 \mathrm{~J}$ Legal Stud 55, 72 (1982).

4 Richard A. Posner, Economic Analysis of Law $\$ 6.15$ at 208 (Little, Brown 4th ed 1992).

${ }^{45}$ See Robert D. Cooter and Edward L. Rubin, A Theory of Loss Allocation for Consumer Payments, 66 Tex L Rev 63, 72 (1987) (“TT]he bargaining costs for insuring the average consumer against fraud and forgery are likely to be large enough to render this insurance either unavailable or too expensive to possess broad appeal."). 
litigation will decrease over the long term. For these reasons, it is at least plausible that initially increasing the number of fraud actions is desirable, and an objection based solely on the volume of litigation fails.

If assignability is likely to lead to an increase in frivolous lawsuits, however, a rule prohibiting the assignability of fraud actions may be desirable. ${ }^{46}$ Comparing assignments with contingency fee arrangements suggests that, on balance, free assignability might lead to an increase in frivolous suits if a deep market for fraud claims develops. However, it is unlikely to do so in the absence of such a market.

At first glance, assignability appears less likely than contingency fee arrangements to encourage frivolous lawsuits. ${ }^{47} \mathrm{~A}$ fraud claim is an asset to the fraud victim: By entering into a contingency fee arrangement, the fraud victim trades an interest in her asset in return for the legal services she needs to convert the asset into a damages judgment or a settlement. ${ }^{48}$ She also spreads to her attorney part of the risk of going to trial. Thus, although contingency fee arrangements are a common target of tort reform proposals, ${ }^{49}$ the arrangements may actually decrease the number of frivolous lawsuits as compared to an hourly wage system by changing the lawyer's incentives.

Professors Kevin Clermont and John Currivan have argued that a lawyer acting out of self-interest should be less likely to take weak claims on a contingency basis than on an hourly basis, because a lawyer working on contingency gets paid only if she wins or settles the suit. ${ }^{50}$ An assignment is like a contingency fee arrangement insofar as it is an agreement allocating the risks and rewards associated with the pursuit of a cause of action. But on a case-by-case basis, an assignee should have even stronger incentives to seek meritorious claims than would a lawyer working on contingency; if she should lose the suit, the assignee will lose not only her time and litigation expenses but also whatever consideration she provided to the assignor. Hence, courts, which

48 Some suits have a low probability of success because they are based on an untested legal theory. Such suits should not be considered frivolous. "Frivolous" is used here to denote only those suits that lack merit on any legal theory.

${ }^{47}$ Contingency fee arrangements are accepted throughout the United States. See Model Code of Professional Responsibility Canon 2, EC 2-20 (ABA 1981) ("Contingent fee arrangements in civil cases have long been commonly accepted in the United States.").

${ }_{43}$ See Choharis, 12 Yale J Reg at 473 (cited in note 40 ).

4 See Martha Middleton, A Changing Landscape, 81 ABA J 56, 56-57 (Aug 1995).

${ }^{50}$ Kevin M. Clermont and John D. Currivan, Improving on the Contingent Fee, 63 Cornell L Rev 529, 571-73 (1978) (arguing that contingent fees may discourage frivolous suits). 
generally uphold contingency fee arrangements, should worry even less about assignments.

It is possible, however, that assignability would increase frivolous fraud suits because assignees who are able to spread risk over many cases would take cases on assignment that they would be unwilling to take on contingency. An assignee can adjust the price she pays for an assignment to reflect the odds of winning. By contrast, states often cap contingency fees, ${ }^{51}$ preventing a lawyer from adjusting her percentage upward beyond a certain point to account for the higher risk involved with a more marginal claim. A risk neutral assignee would be indifferent between paying $\$ 5,000$ for a claim she estimates has a 75 percent chance of resulting in a $\$ 10,000$ award $(.75 * \$ 10,000=\$ 7,500$; $\$ 7,500-\$ 5,000=\$ 2,500$ ), and paying $\$ 1,000$ for a claim she estimates has a 35 percent chance of winning $\$ 10,000(.35 * \$ 10,000$ $=\$ 3,500 ; \$ 3,500-\$ 1,000=\$ 2,500$ ). A lawyer working on a contingency basis, however, may not have the flexibility to adjust her percentage fee in order to make her indifferent between the claims. Suppose she were willing to take one-third of a claim she estimates has a 75 percent chance of winning $\$ 10,000$ (.75* $\$ 10,000=\$ 7,500$; one-third of $\$ 7,500=\$ 2,500$ ). If she could not increase her cut of the damage award above one-third, she would be unable to adjust for any increased risk and would thus be unwilling to take a claim she estimates has only a 35 percent chance of winning $\$ 10,000$. As a result, she would be willing to take a claim on assignment that she would be unwilling to take on contingency.

The contingency fee cap means that low probability claims may be attractive as assignments where they are not attractive in a contingency fee arrangement. However, even if lawyers could choose between taking cases on contingency and taking them by assignment, ${ }^{52}$ outside factors make it unlikely that lawyers will be risk neutral. First, plaintiff' firms are generally not large enough to be able to spread the risk of taking a lot of claims with a low probability of success. ${ }^{53}$ Similarly, most law firms are or-

${ }^{61}$ See, for example, 4 Cal Bus \& Prof Code $\S 6146$ (West 1990) (limiting fees in medical malpractice suits to 40 percent of the first $\$ 50,000,331 / 3$ percent of the next $\$ 50,000$, and so on with declining percentages); Lisa Bernstein and Daniel Klerman, An Economic Analysis of Mary Carter Settlement Agreements, 83 Georgetown L J 2215, 2238 n 65 (1995) (noting that many states place strict limits on maximum allowable contingent fees).

${ }^{62}$ See note 93 and accompanying text for a discussion of the legal limits that prevent lawyers from prosecuting claims by assignment.

${ }^{63}$ See Choharis, 12 Yale J Reg at 477 (cited in note 40) (arguing that plaintiffs' firms are unlikely to achieve the size necessary to be able to bear the risk of purchasing all of a claim because the collective decisionmaking costs in the partnership form are prohibitive). 
ganized as partnerships, and partnerships have a more limited capacity to bear risk than other organizational forms. ${ }^{54}$ Furthermore, the reputational effects of trying many losing claims are significant to lawyers, who must protect their reputations in order to ensure continued business. Nonattorney claim speculators, on the other hand, may be in a better position to spread risk among many marginal claims and may be more likely to be indifferent to reputational effects of losing..$^{55}$ Thus, a market for fraud claims involving nonattorneys might lead to an increase in the number of marginal fraud claims filed. ${ }^{56}$

Assignees also might file frivolous claims in an attempt to coerce settlements out of innocent defendants, exploiting the fact that defendants often have higher litigation costs than plaintiffs and thus may be less willing to litigate. ${ }^{57}$ Characteristics of fraud claims, however, make such claims less susceptible than other tort claims to use in harassing lawsuits. Fraud is a difficult claim to litigate. Indeed, fraud is more constrained than many torts because the elements that a fraud plaintiff must prove are strictly defined and difficult to prove. ${ }^{58}$ Moreover, plaintiffs must plead fraud with particularity. ${ }^{59}$ Thus, the concern that permitting the assignment of fraud claims will lead to frivolous lawsuits is overstated; there is less reason to fear harassing lawsuits based on fraud than there is to be concerned about harassing lawsuits based on counts of negligence.

An additional claim courts and commentators make to justify the nonassignability rule is that determining the value of a fraud claim is so speculative that fraud victims will end up being systematically undercompensated when they assign their claims. In Caldwell v Ogden Sea Transport, Inc, ${ }^{60}$ the Fourth Circuit stated that one purpose "of the general rule of non-assignability of

See id at 476-79.

see id.

s See Part III for a discussion of the legal limits on claim speculation by attorneys and nonattorneys alike. These limits currently constrain the development of a deep market for fraud claims.

${ }^{57}$ See John C. Coffee, Jr., Understanding the Plaintiffs Attorney: The Implications of Economic Theory for Private Enforcement of Law Through Class and Derivative Actions, 86 Colum L Rev 669, 701-02 (1986) (arguing that defendants may often have higher litigation costs than plaintiffs).

See Asbury Park \& Ocean Grove Bank v National City Bank of New York, 35 NYS 2d 985, 989 (NY Sup Ct 1942) (stating that "[ $t]$ he common-law fraud action is one of the most difficult to prove").

See Chesapeake Microfilm, Inc v Eastern Microfilm Sales and Service, Inc, 91 NC App 539, 372 SE2d 901, 903 (1988). See also FRCP 9(b) (requiring plaintiffs to plead fraud with particularity).

$\infty 618$ F2d 1037 (4th Cir 1980). 
claims for personal injury ... [is] to prevent unscrupulous strangers to an occurrence from preying on the deprived circumstances of an injured person." Indeed, Marc Shukaitis, in an article advocating a market in negligence-based claims, acknowledges that some unscrupulous claim purchasers will take advantage of unsophisticated tort victims. ${ }^{62}$ He suggests, however, that a market for claims could only improve the current situation, where a tort victim has only one buyer for her claim-the tortfeasor. ${ }^{63}$ Moreover, "[e]ven in the absence of regulation, buyer behavior would be constrained by purchase price competition of other potential buyers. ${ }^{34}$ Thus, market competition would prevent the systematic exploitation of claimholders.

In the absence of a deep market for fraud claims, tort victims may indeed have difficulty knowing how to value their claims. There is little reason to believe, however, that it will be more difficult for victims of fraud to determine the value of their claims for assignment than it already is for the choice between settling, going to trial, or doing nothing. Moreover, tort victims will not have to assess the value of claims in the abstract. Instead, they will be able to compare options. When our beach club plaintiff goes to the other victims of the beach club scam and offers to purchase their claims, they can decide whether they prefer to keep the claims (for which individual litigation might be prohibitively expensive) or assign them to our plaintiff. The sum he offers may fail to compensate them fully for their losses, but they are likely to consider any sum better than nothing.

In a second-best world with fixed litigation costs, the choice to assign looks like a good choice, not a choice from which the law should protect fraud victims. Moreover, the assignee will only have to prove certain elements of the fraud claim one time, so the consolidation should reduce litigation costs. Additionally, a trier of fact faced with multiple claims may find the claims more persuasive together than on their own. For either reason, assignment could make the claims more valuable and thus increase the amount of money the assignee is willing to pay for them. In any event, fraud victims can always refuse an offer.

But even if fraud victims would sell their claims for less than the present value of the claims, it is unreasonable to prohibit assignment on that basis, because fraud victims may have high dis-

\footnotetext{
${ }^{61}$ Id at 1048 .

22 Shukaitis, $16 \mathrm{~J}$ Legal Stud at 347 (cited in note 40 ).

${ }^{63}$ Id at $335 \mathrm{n} 6,347$.

at Id at 347.
} 
count rates. ${ }^{65}$ Such rates might at first seem to present a reason for limiting assignability. Indeed, Professor Owen Fiss has made an objection to settlement that is similar to this objection to assignment, reasoning that tort victims might, as a result of their injuries, be vulnerable to settling claims for less than present value:

[The tort victim] may need the damages he seeks immediately and thus be induced to settle as a way of accelerating payment, even though he realizes he would get less now than he might if he awaited judgment. All plaintiffs want their damages immediately, but an indigent plaintiff may be exploited by a rich defendant because his need is so great that the defendant can force him to accept a sum that is less than the ordinary present value of the judgment. ${ }^{66}$

That tort victims may discount their expected judgments steeply does not, however, justify prohibiting assignment. If the victim believes the value of his expected judgment decreases by a certain percentage for each additional day that he has to wait for it, he should be free to act accordingly. Courts should not impose a requirement that denies tort victims the compensation options they believe are best for themselves. So long as courts permit settlement in civil suits, the potentially high discount rate of tort victims does not present a valid argument against assignment.

Courts might also fear that assignees may buy up fraud claims that are sold at a deep discount and sell them back to the tortfeasor at a profit, but for less than the cost of the injury imposed. This policy objection is similar to the one made against some settlements: ${ }^{67}$ the assignee makes a profit, the tortfeasor buys the right to commit fraud at a discount, and the victims end up undercompensated for their injuries. In short, the scenario thwarts the tort system's twin aims of deterrence and victim compensation.

This scenario assumes, however, that the assignee will be willing to settle with the tortfeasor for less than the present value of the expected judgment. This assumption may not hold true. Whether the assignee is also a victim, like our beach club plaintiff, or a claim speculator holding a number of claims, by invest-

${ }^{65}$ See Richard A. Posner, An Economic Approach to Legal Procedure and Judicial Administration, $2 \mathrm{~J}$ Legal Stud 399, 420 (1973).

${ }^{B 6}$ Owen M. Fiss, Against Settlement, 93 Yale L J 1073, 1076 (1984).

${ }^{67}$ See Marc Fisher, Class Actions' Big Winners: The Lawyers; Huge Fees Contrasted with Plaintiff Benefits, Wash Post A1 (May 25, 1997); Reed Abelson, Settlements Earn Lawyers Cash, Customers Coupons, Cin Enq A6 (Aug 28, 1997). 
ing in the claims he signals that he is in a better position to bear the cost of delay associated with litigation than is an ordinary tort victim. Because the assignee has chosen to invest in the claim rather than being involuntarily vested with it by being the victim of a tort, we can be confident that he will be in a good position to compare-without a steep discount for delay-the value of a settlement with the value of an expected judgment. Accordingly, he will be less likely than an ordinary tort victim to settle for anything less than the present value of the expected judgment (minus the expected cost of litigation). ${ }^{68}$ Thus, assignment may actually increase deterrence by ensuring that tortfeasors cannot take advantage of tort victims' discount rates and settle for less than the real cost of the injuries they impose. Moreover, even if one accepts that fraud victims will assign claims for less than their present value, prohibiting assignment to prevent this from happening is cold comfort to tort victims; from their perspective, some compensation is better than no compensation.

Moreover, while assignment may not perfectly achieve the compensatory goal of the tort system, allowing plaintiffs to pursue claims together will promote deterrence. Under the current system, a tortfeasor can impose collectively large costs on people without reprisal as long as the individual harms are small enough that the fixed costs of litigation make it impractical for any single victim to file a claim. ${ }^{69}$ Although class actions theoretically answer this problem, fraud is difficult to pursue as a class action because the element of reliance often prevents fraud plaintiffs from meeting the commonality requirement. ${ }^{70}$ Thus, allowing individuals such as the beach club plaintiff to pursue assigned claims may deter fraud substantially by facilitating meritorious fraud claims that otherwise would never be brought. The tortfeasor would no longer be able to avoid paying a judgment simply by spreading the cost he imposes among many individuals. Assignment will therefore increase deterrence. ${ }^{71}$

${ }^{68}$ See A. Mitchell Polinsky, An Introduction to Law and Economics 107-15 (Little, Brown 2d ed 1989) (discussing the economics of settlement).

${ }^{69}$ See Posner, Economic Analysis \& 21.9 at 569-70 (cited in note 44).

${ }^{70}$ See FRCP 23(a), (b)(3); In re Woodward \& Lothrop Holdings, Inc, 205 Bankr 365, 371 (S D NY 1997) ("A class action is generally not appropriate to resolve claims based upon common law fraud because each class member must prove his or her own reliance."); Bunch v Kmart Corp, 898 P2d 170, 172 (Okla App 1995) (holding that each plaintiff in a common law fraud suit must prove reliance); In re Synergen, Inc Securities Litigation, 154 FRD 265, 267 (D Colo 1994) (same); Klemow v Time Inc, $466 \mathrm{~Pa} 189,352$ A2d 12, $16 \mathrm{n} 17$ (1976) (same).

${ }^{7}$ For the purpose of deterrence, it does not matter to whom the tortfeasor pays a judgment, it only matters that he pays for his actions. 
Courts also have suggested that the prohibition on assignment is necessary because without it assignors will exaggerate their injuries or overstate the strength of their cases in the hope of persuading others to purchase their claims. Once the claim sells, the assignor is stuck with his story. These courts also note the possibility that the assignor and assignee will collude against the tortfeasor if they are allowed to make an arrangement regarding the claim, with the assignee coaching the assignor to exaggerate the claim in order to make good on the deal. ${ }^{72}$

However, if assignees are repeat players, they should be in a good position to learn how to protect themselves from exaggerated claims. There is no reason for caveat emptor not to apply in this context. Additionally, it is not clear why an assignor would be more likely to collude with an assignee bringing a claim than he would be to engage in similar actions on his own behalf, unless he corners himself by exaggerating his claim in order to sell it. ${ }^{73}$ In any event, there are legal remedies for collusion short of a complete prohibition on assignment. For example, in Coffey $v$ Jefferson County Board of Education, ${ }^{74}$ the court voided an assignment because it seemed so collusive as to violate public policy. ${ }^{75}$

In sum, the most significant claim made in favor of the prohibition on assignability is that free assignability will lead to an increase in the number of frivolous fraud claims filed. It is not clear, however, whether this claim is accurate. But even if it is correct, the prohibition on the assignment of fraud claims carries significant costs: it sacrifices potential deterrence gains and decreases the likelihood that fraud victims will receive some compensation for their injuries. On balance, these costs outweigh the benefits that the nonassignability rule may secure.

\section{B. A Rule Distinguishing Among Fraud Claims}

A rule that requires courts to determine which fraud claims arise out of personal injuries and which arise out of injuries to property imposes higher decision costs on courts and greater uncertainty on potential assignees than a bright line rule for or against assignability. Whether such a rule is desirable depends on the extent to which the rule helps courts avoid errors that they

72 See note 35 and accompanying text.

${ }^{73}$ See Goldstein, 97 Comm L J at 269 n 48 (cited in note 35) (arguing that the tendency to exaggerate is probably equally as strong whether a plaintiff assigns a claim or pursues it directly, but acknowledging that additional empirical research is needed).

${ }^{24} 756$ SW2d 155 (Ky App 1988).

${ }^{75}$ Id at 156-57 (The defendant in a negligence suit confessed judgment and then tried to assign a malpractice claim against his attorney to the plaintiff on the day of trial.). 
would make if they used a bright line rule. To put it another way, one should ask to what extent a bright line rule would allow claims to be assigned that should not be assigned or prohibit claims from being assigned that should be assignable. The costs of these errors should be balanced against the lower decision costs of a bright line rule.

The main justification courts offer for distinguishing among claims and prohibiting the transfer of personal claims, the one offered by courts that use "personal" to mean directed at the personhood of the victim, is that assignment of these claims is undesirable because courts should not allow litigants to treat as commodities injuries that are directed at the victim's personhood. ${ }^{76}$

In some assignment scenarios, it is difficult to understand how this objection could be relevant to assignment but not to settlement. Indeed, a fraud victim who settles with the tortfeasor sells her claim just as surely as a fraud victim who assigns her claim. When the assignment is made to a fellow victim, as in the beach club scenario, assignment seems virtually indistinguishable from settlement.

On the other hand, if a deep market for fraud claims were to develop, assignment would be distinguishable from settlement because assignment would bring strangers into the dispute. The objection, then, seems to be one of degree: the legal system recognizes settlement out of necessity, but it is going too far to allow sale to a stranger when the claim is thought to be personal. Treating a cause of action for a personal injury as a commodity sends the wrong message about fraud-that is, that a violation of the right to be free from fraud is fully interchangeable with money.

This objection, however, ignores the important distinction between selling the right to commit fraud against oneself and selling the right to pursue a cause of action for fraud already committed. Moreover, the objection turns on the controversial notion that the purpose of a cause of action for fraud is to avenge the wrong done by the tortfeasor and to express social condemnation for the tortious act. ${ }^{77}$ The argument is that revenge, being intan-

${ }^{78}$ See Gilboy v American Tobacco Co, 540 S2d 391, 393 (La App 1989) (noting that "[t]he law has been well settled ... that a transfer of a personal injury cause of action during the lifetime of the injured party is not permitted because of the intensely personal nature of such actions"); Wittenauer, 15 SW2d at 462 ("[T] permit one's pain and suffering to become a matter of speculation is not looked upon with favor by the law."); Choharis, 12 Yale J Reg at 525 (cited in note 40) ("Many in our legal culture maintain as an article of faith that selling tort claims is bad for society and for those who would do so.").

"See David G. Owen, Deterrence and Desert in Tort: A Comment, 73 Cal L Rev 665, 668-69 (1985) (discussing the role of retribution in the tort system); Steven D. Smith, The 
gible and personal to the victim, cannot properly be transferred. Similarly, if the underlying purpose of the tort system is to express condemnation for tortious acts, assignment may diminish that function by allowing trade in claims. These arguments privilege revenge and condemnation at the expense of compensation and deterrence. Protecting fraud victims from having their injuries treated as commodities by restricting their freedom to obtain compensation amounts to misguided paternalism.

Objections to assignment of personal fraud claims also seem to rest on a desire to protect public sensibilities. Because plaintiffs can characterize many different injurious acts as fraud, ${ }^{78}$ the category of cases involving actionable fraud is broad and includes cases that are personal in the sense that they involve personal relationships. ${ }^{79}$ Perhaps courts fear that advertisements on latenight television by claim speculators trolling for fraud victims might bring private disputes into the public domain. Although such advertisements would likely offend some people's sensibilities, they might also make the public more aware of what constitutes actionable fraud. Such awareness would provide another source of deterrence. Moreover, if courts disfavor these causes of action, they should prohibit them, not ban assignment. If the court recognizes the claim, it is not justified in attempting to keep the courts (and airwaves) free from such disputes.

Courts might also reason that limiting assignment of personal claims provides an effective means of protecting involuntary assignors. A bankrupt individual might have reasons not to

Critics and the "Crisis": A Reassessment of Current Conceptions of Tort Law, 72 Cornell L Rev 765, 766 (1987) (arguing that the tort system's primary function "is not to compensate, deter, or punish, but rather to resolve disputes arising from perceived breaches of important social norms, thereby reducing conflict and reaffirming those norms").

${ }^{78}$ See, for example, Stricker $v$ Epstein, 213 Ga App 226, 444 SE2d 91, 94 (1994) (holding that evidence of agreement to sell stock in one corporation but use the money for another corporation is sufficient to establish fraud); Aaron $v$ Allstate Insurance Co, 559 S2d 275, 276-77 (Fla Dist Ct App 1990) (characterizing an insurance company's failure to provide an adequate defense as fraud); Kathleen $K v$ Robert $B ., 150$ Cal App 3d 992, 198 Cal Rptr 273, 276-77 (1984) (recognizing claim for fraud alleging that respondent deliberately misrepresented to appellant that he was free from venereal disease and infected respondent with genital herpes); Wishnick $v$ Frye, 111 Cal App 2d 926, 245 P2d 532, 534-35 (1952) (holding that corporate officers and directors who misrepresent facts to investors are subject to liability for fraud, although finding a lack of scienter in the present case); Snyder v Schneider, 154 Misc 26, 276 NYS 445, 446-47 (NY Sup Ct 1935) (permitting action of fraud in falsely inducing a marriage when person had a living spouse).

7see Paula C. Murray and Brenda J. Winslett, The Constitutional Right to Privacy and Emerging Tort Liability for Deceit in Interpersonal Relationships, 1986 U Ill L Rev 779, 779-80 (describing increasing use of common law tort actions, including fraud, in suits for physical, emotion, and financial injuries resulting from fraudulent conduct in sexual relationships, including false representation of lack of sexually transmitted disease and misrepresentation regarding the use of birth control). 
pursue a fraud claim that a trustee would not consider; for example, a long-term interest in maintaining a relationship with the potential defendant. When rights are transferred involuntarily, limiting the assignment of claims that are personal is one way to prevent a third party from pursuing a claim against the will of an involuntary assignor.

There are better ways to protect the interests of involuntary assignors than barring assignment. Courts could instead require that the assignor agree that he was defrauded before the assignee is free to pursue a claim for fraud. Cases involving analytically similar situations support the proposition that an assignee should not be able to pursue claims that the assignor does not recognize.$^{80}$ Furthermore, as a practical matter, it is unlikely that a suit will succeed if the victim, who almost certainly will be required to testify, does not wish the claim to be pursued.

In sum, the most powerful argument in favor of limiting the assignment of personal claims is that assignment expresses the wrong message about the consequence of injuring others by defrauding them. This objection, however, ignores the important distinction between selling the right to be free from fraud and selling the right to seek a remedy for an already sustained injury. The objection does not justify the higher decision costs involved in adopting a distinguishing rule. Moreover, it does not justify forgoing the added deterrence that will result from permitting the assignment of personal claims.

\section{A Rule Allowing the Assignment of All Fraud Claims}

If a deep market for fraud claims were to develop in response to free assignability, it would have several desirable effects. In the context of negligence-based claims, Marc Shukaitis has argued that a market for claims would: (1) increase the value of compensation that tort victims receive (because claim speculators would be able to offer victims better deals than attorneys working on contingency fees); (2) increase victims' access to compensation; (3) provide victims with greater control over the results of their claims; and (4) increase deterrence. ${ }^{81}$

\footnotetext{
${ }^{\infty}$ See, for example, Chittick v State Farm Mutual Auto Insurance Co, 170 F Supp 276, 280 (D Del 1958) (holding that judgment creditor was not entitled to try issue of liability of insurance company to insured); Murray $v$ Mossman, 56 Wash 2d 909, 355 P2d 985, 988 (1960) (refusing to allow creditor of insured to pursue action against insurer when the insured did not believe a claim existed); Paul v Kirkendall, 6 Utah 2d 256, 311 P2d 376, 37980 (1957) (same).

${ }^{81}$ Shukaitis, $16 \mathrm{~J}$ Legal Stud at $334-41$ (cited in note 40 ).
} 
Peter Choharis has argued-also in the area of negligencebased torts-that in addition to these benefits, a deep claims market would eliminate certain problems inherent in the current class action system. ${ }^{82} \mathrm{He}$ disagrees with Shukaitis that lawyers are well-suited to be the key participants in the market and argues that the development of a secondary market in tort claims would increase liquidity, reduce the cost of capital for claim speculators, and erode the lawyers' oligopsony. ${ }^{83}$

Shukaitis and Choharis agree that a market for claims would reduce the agency costs of contingency arrangements and class actions. ${ }^{84}$ Commentators have noted that stakeholders in contingency arrangements and class actions may face conflicting interests when deciding between accepting a settlement offer or going to trial. ${ }^{85}$ In contrast, because the assignor transfers all or most of her interest in the claim, an assignment eliminates or reduces significantly the prospect of a conflict of interest between assignor and assignee. ${ }^{86}$

Because of the unique nature of fraud, two of these benefits would be magnified. First, as discussed in Part II.A, fraud, as an intentional tort, is more susceptible to deterrence than are negligence-based torts. Hence, the argument that a market for claims will increase deterrence is stronger for fraud claims than for negligence claims. Moreover, this deterrence argument does not apply only to legally sophisticated tortfeasors. If an active market for fraud claims makes the public more aware of fraud actions, some fraud victims who currently never file suit would do so. Moreover, even if the actual number of suits does not increase,

${ }^{2}$ Choharis, 12 Yale J Reg at 445 (cited in note 40 ) (listing interclass rivalries and protracted bankruptcy procedures as problems that a market would avoid).

${ }^{3}$ Id at 444-46, 475-79. An oligopsony is a market with a small number of buyers. Shukaitis, $16 \mathrm{~J}$ Legal Stud at 335 n 36 (cited in note 40 ).

* Choharis, 12 Yale J Reg at 444-46, 480-81 (cited in note 40); Shukaitis, $16 \mathrm{~J}$ Legal Stud at 338-41 (cited in note 40 ).

ss See Geoffrey P. Miller, Some Agency Problems in Settlement, $16 \mathrm{~J}$ Legal Stud 189, 190 (1987) (noting that in contingency fee arrangements, "the interests of plaintiff and attorney are never perfectly aligned... . When the defendant has made a lump-sum offer of settlement, the attorney's interest may often call for accepting the offer, but the plaintiff might be better off going to trial."); Clermont and Currivan, 63 Cornell L Rev at 536 (cited in note 50) (noting that contingency fee lawyers have a direct economic incentive to "obtain a respectable settlement with relatively slight effort").

${ }^{83}$ As Shukaitis and Choharis have pointed out, assignment does present agency problems of its own; assignees will have to have some way of ensuring that the assignors would assist them at trial. Choharis, 12 Yale $\mathrm{J}$ Reg at 481-82 (cited in note 40); Shukaitis, $16 \mathrm{~J}$ Legal Stud at 340-41 (cited in note 40). Choharis argues it would be possible to significantly reduce this problem by contracting with the assignor to pay some portion of the consideration after suit or settlement, or by offering a bonus payment based on future contingencies. See Choharis, 12 Yale J Reg at 482 (cited in note 40). 
tortfeasors' evaluation of their potential liability may be altered. Thus, added awareness resulting from an active market could deter fraud by both increasing the number of fraud claims and increasing tortfeasors' estimation of the odds that they will be held responsible for their fraudulent acts.

Second, because individuals are a lot less likely to have insurance against fraud than against injury, ${ }^{87}$ the compensatory role of the tort system for fraud is more significant than for negligence claims. Some victims of fraud who currently go uncompensated would get some compensation for their injuries through a market for fraud claims. Also, where a fraud victim can assign her claim, she can get an immediate and sure payoff instead of waiting through the delay and uncertainty of litigation.

\section{BARRIERS TO A DEEP MARKET FOR FRAUD CLAIMS}

Practical and legal obstacles, for lawyers and nonlawyers alike, make it unlikely that a deep market for fraud claims will develop in the absence of significant statutory change.

First, mass fraud claims present a number of practical difficulties for claim speculators. Fraud claims present fewer opportunities than mass torts for assignees to save on duplicative costs such as discovery and expert fees. Moreover, they are not nearly as attractive because plaintiffs alleging fraud must prove individual reliance. ${ }^{88}$ In practice, this means the assignee will have to have some way of ensuring that the assignor will assist him if the claim goes to trial. ${ }^{89}$ Plaintiffs must also plead all the elements of fraud with particularity. ${ }^{90}$ Thus, the economies achieved by consolidating negligence claims through an assignment would be reduced with fraud claims.

Another practical barrier to widespread trading in all tort claims is that assignees of single-victim claims and multi-victim claims alike face enormous information costs. Speculation in claims would therefore require substantial expertise. For example, without some means of ensuring that a claim is recoverable from a defendant or a solvent insurer, ${ }^{91}$ assignments may be un-

${ }^{87}$ See note 45 and accompanying text.

See note 2.

See Choharis, 12 Yale J Reg at 481-83 (cited in note 40). Choharis suggests a variety of mechanisms assignees may use to protect their interests, for example, making assistance at trial an explicit part of the assignment agreements. Id at 482.

${ }^{\infty}$ See note 59.

${ }^{91}$ See Michael Sean Quinn, On the Assignment of Legal Malpractice Claims, $37 \mathrm{~S}$ Tex L Rev 1203, 1216-17 (1996). 
attractive to speculators. Investigating potential defendants is both difficult and costly. ${ }^{22}$

Moreover, even if claim speculators could surmount these barriers, they would still face other legal impediments. Many states explicitly prohibit attorneys from pursuing claims on assignment, so it could be difficult for lawyers to speculate in claims. ${ }^{93}$ And as for nonattorneys, buying and pursuing claims likely would constitute unauthorized practice of law. ${ }^{94}$ Accordingly, in many jurisdictions it would be illegal for both attorneys and nonattorneys to develop a claim speculating business without a change in the laws.

Present ethical and legal prohibitions on the development of a claim speculation business also prevent the development of a deep market for fraud claims. These prohibitions protect lawyers' interests at the expense of fraud victims (and victims of other torts). Limiting assignment reduces competition for claims and makes contingency arrangements the only option available to many plaintiffs, if it is available at all. Repeat defendants and plaintiffs' attorneys-both organized interest groups-have incentives for retaining the status quo: the present system allows plaintiffs' attorneys to avoid competition for claims and allows repeat defendants to impose widespread, low-level fraud without fear of reprisal. The ethical bar on attorney claim speculation and regulations against the unauthorized practice of law hurt fraud victims, a group with no corresponding level of organization or influence. Until these prohibitions are lifted, a deep market for fraud claims cannot develop.

$n$ Choharis argues that a secondary market in claims will make these costs less prohibitive to nonattorney claim purchasers. Choharis, 12 Yale J Reg at 500 (cited in note 40).

See, for example, La Civ Code Ann $\$ 2447$ (West 1996) (prohibiting sale of litigation rights to any officer of court); $1983 \mathrm{NY}$ Jud Laws $\S 489$ ("No person or co-partnership, engaged directly or indirectly in the business of collection and adjustment of claims ... shall solicit, buy or take an assignment of . . . any claim or demand, with the intent and for the purpose of bringing an action or proceeding thereon."); Fairchild Hiller Corp v McDonnell Douglas Corp, 28 NY2d 325, 321 NYS2d 857, 270 NE2d 691, 693 (1971) (stating that the New York legislature enacted the predecessor statute to Section 489 "[t]o prevent the resulting strife, discord and harassment which could result from permitting attorneys and corporations to purchase claims for the purpose of bringing actions thereon").

* See Jack Faucett Associates, Inc v AT\&T Co, 1985 WL 25746, *7 (D DC) (unreported opinion) (finding that company engaged in the unauthorized practice of law when it solicited potential legal claims from the class of plaintiffs); Brown $v$ Unauthorized Practice of Law Committee, 742 SW2d 34, 41 (Tex App 1987) (holding that the practice of law "embraces in general all advice to clients and all action taken for them in matters connected with the law" and that a person may confer legal advice by a course of conduct that encourages litigation and the prosecution of claims). 
Even in the absence of a deep market for fraud claims, however, permitting assignment is desirable. As the beach club example illustrates, assignment can resolve the collective action problem that occurs in multi-victim cases with low individual damages. This benefit is particularly valuable in fraud cases, because fraud is difficult to pursue as a class action. Hence, assignment could help alleviate both the undercompensation and the underdeterrence that is present in cases such as the beach club case. Assignment also has the advantage of eliminating distribution of award problems associated with class actions. ${ }^{95}$

Other situations also show that, even absent a fully developed market for fraud claims, free assignability could promote efficient allocation of resources devoted to claims. ${ }^{96}$ Victims of fraud may face economic hardship as a result of the fraud and allowing them to assign their fraud claims to their creditors may provide them with financial stability. Peterson $v$ Brown, ${ }^{97}$ a recent Minnesota case, illustrates this point. The case involved an allegation of fraud based on a failure to obtain insurance. ${ }^{98} \mathrm{~A}$ motel owner paid a deposit on an insurance policy for "full coverage." After two motel employees died in a fire, the insurance company denied coverage, claiming that the policy did not cover the employees' injuries. The motel owner assigned his fraud claim against the insurance company to the representatives of the employees killed in the motel..$^{99}$ Allowing the motel owner to assign his claim to the decedents' representatives ensured that the party pursuing the claim was the party who stood to benefit from it; any judgment won by the motel owner would have gone directly to the decedents' estates anyway. Moreover, allowing assignment helped counteract the possibility that the motel owner would decide it was better for him to declare bankruptcy than to pursue the fraud claim. Although the fraud claim would pass to the bankruptcy estate, the trustee would have difficulty pursuing it without the cooperation of the motel owner, so the tort creditor could end up with no compensation. As this example shows, free assignability promotes de-

${ }^{95}$ See Posner, Economic Analysis of Law $\S 21.9$ at 570 (cited in note 44) (discussing the problem of distributing awards in class actions where the individual plaintiff award is very small).

${ }^{8}$ The Supreme Court of Maine upheld the assignment of legal malpractice claims on efficiency grounds: assignment allows the assignor to "[realize] the value of its malpractice claim in what may be the most efficient way possible, namely, its assignment to someone else with a clear interest in the claim who also has the time, energy and resources to bring the suit." Thurston $v$ Continental Casualty Co, 567 A2d 922, 923 (Me 1989).

${ }^{n} 457$ NW2d 745, 748-49 (Minn App 1990) (holding claim for fraud assignable).

Id at 746 .

Id at 746-47. 
terrence and compensation even absent a deep market for fraud claims.

\section{CONCLUSION}

The policy arguments offered to support the prohibition on assigning fraud claims are unconvincing. Permitting assignments between interested individuals will ensure that fraud claims end up in the hands of the individual most likely to pursue the claims vigorously. It will thus promote deterrence by ensuring that fraud tortfeasors are forced to pay for their acts and will increase the probability that victims of fraud will be compensated. Unfortunately, practical and procedural impediments presently prevent the development of a widespread trade in fraud claims. Ethical objections to assignment-which protect lawyers' interests at the expense of tort victims-also impede the development of such a trade. In light of the benefits assignment provides both to fraud victims and society generally, legal impediments that stand in the way of assignability should be eliminated. 


\section{APPENDIX}

1. Cases and statutes holding that all fraud claims are assignable.

Micheletti $v$ Moidel, 94 Colo 587, 32 P2d 266, 268 (1934) (holding that claims for fraud are assignable); Kleinwort Benson North America, Inc $v$ Quantum Financial Services, Inc, 1998 Ill LEXIS 343, *5-6, *15 (noting that common law fraud claims are assignable); Red Giant Oil Co $v$ Lawlor, 528 NW2d 524, 533 (Iowa 1995) (affirming that choses in action for contract and tort are assignable); Medical Mutual Liability Insurance Society of Maryland $v$ Evans, 330 Md 1, 622 A2d 103, 116-17 (1993); Mason v Vogue Knitting Corp, 365 Mich 552, 114 NW2d 154, 156 (1962) (holding that all causes of action for fraud survive and therefore are assignable); Jandera $v$ Lakefield Farmers' Union, 150 Minn 476, 185 NW 656, 658 (1921) (holding that a cause of action for fraud is not a personal injury and is therefore assignable); Peterson v Brown, 457 NW2d 745, 749 (Minn App 1990) (reaffirming Jandera); Leavenworth \& Son, Inc $v$ Hunter, 116 S 593, 596 (Miss 1928) (holding that an action for injury to person or property is assignable); Stroman v Atlas Refining Corp, 112

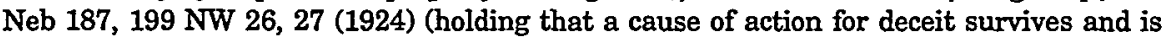
assignable); Fox $v$ Hirschfeld, 157 AD 364, 142 NYS 261, 263 (NY App Div 1913) (noting that fraud claims are assignable); Sherman $v$ Harris, 36 SD 50, 153 NW 925, 927-28 (1915) (holding claim for deceit assignable), affd on rehearing, 40 SD 341, $167 \mathrm{NW} 325$, 325 (1918), overruled on other grounds, Simons $v$ Kidd, 73 SD 280, 41 NW2d 840 (1950); McLaury $v$ Watelsky, 39 Tex Civ App 394, 87 SW 1045, 1049 (1905) (holding that all causes of action are assignable); Miller $v$ Starcher, 86 W Va 90, 102 SE 809, 809-10 (1920) (holding cause of action for fraud assignable); Chimekas $v$ Marvin, 25 Wis $2 \mathrm{~d}$ 630, 131 NW2d 297, 299 (1964) (holding that a cause of action for fraud is assignable); Wyo Stat $\$ 1-4-101$ (1997) (providing that a cause of action for deceit survives); Stilson $v$ Hodges, 934 P2d 736, 738 (Wyo 1997) (noting that causes of action for damage to persons and property survive and are assignable).

2. Cases and statutes holding that fraud claims (of all types) are not assignable.

Generali-US Branch $v$ Southeastern Security Insurance Co, 229 Ga App 277, 493 SE2d 731, 735-36 (1997) (holding that fraud claims are not assignable); Kan Stat Ann § 60-1801 (1983) (providing that causes of action for fraud survive); Joe Cooper \& Associates, Inc $v$ Central Life Assurance Co, 614 S2d 982, 990 (Ala 1990) (interpreting Kansas statutes to hold that fraud claims are not assignable in Kansas); National Shawmut Bank of Boston $v$ Johnson, 317 Mass 485, 58 NE2d 849, 851 (1945) (holding that fraud claims are not assignable); Prosky $v$ Clark, 32 Nev 441, 109 P 793, 794 (1910) (holding that rights of action based on fraud are not assignable); Costanzo $v$ Costanzo, 248 NJ Super 116, 590 A2d 268, 271 (1991) ("A tort claim is a chose in action and at first blush it would appear to be assignable. But in New Jersey, as a matter of public policy, a tort claim cannot be assigned."); 12 Okla Stat Ann \& 2017(d) (West 1993) (providing that assignment of claims not arising out of contracts is prohibited); Dippel $v$ Hunt, 517 P2d 444, 447 (Okla App 1973) (adopting the common law rule that the assignment of a personal tort is not allowed); Chimney Rock Limited Partnership v Hongkong Bank of Canada, 857 P2d 84, 88 (Okla App 1993) (explaining that torts arising out of contract relationships are assignable); Jones $v$ Ellis' Estate, $68 \mathrm{Vt} 544,35 \mathrm{~A} 488,489$ (1896) (holding that action for fraud on sale of stock does not survive under survival statute).

3. Cases and statutes holding that assignability of fraud claim depends on whether it arises out of a personal injury or an injury to property.

All States Life Insurance Co $v$ Jaudon, 228 Ala 672, 154 S 798, 800 (1934) (stating that rule that right of action for tort is unassignable as applied to fraud claim resulting in wrong to person); Whitney $v$ Kelley, 94 Cal 146, 29 P 624, 625 (1892) (prohibiting the assignment of the right to sue for fraud where the party assigning the right did not have some capacity for personal judgment); Jackson $v$ Deauville Holding Co, 219 Cal 498, 27 P2d 643, 643-44 (1933) (holding the assignment of fifty-one fraud claims valid because the claims were attached to property interests); Metropolitan Life Insurance Co v Fuller, 61 
Conn 252, 23 A 193, 196 (1891) (holding that "the sale of an interest to which a right to sue is incident is good, but the sale of a mere right to sue is bad"); Aaron $v$ Allstate Insurance Co, 559 S2d 275, 277 (Fla Dist Ct App 1990) ("AA] cause of action, which is not based on a personal tort such as malpractice, may be assignable.”); MacLeod $v$ Stelle, 43 Idaho 64, 249 P 254, 257 (1926) (holding cause of action for fraud in sale of stock assignable because survivable as an injury to property); Kloepfer $v$ Forch, 32 Idaho 415, 184 P 477, 47778 (1919) (noting that the assignability of a tort cause of action depends on the nature of the claim); Beall $v$ Farmers' Exchange Bank of Gallatin, 76 SW2d 1098, 1099 (Mo 1934) (holding fraud cause of action is assignable when attached to a property interest, but is not assignable when the wrong is to the person); Property Exchange \& Sales, Inc $v$ Bozarth, 778 SW2d 1, 2 n 1 (Mo App 1989) ("An action for fraud is assignable where the wrong is not regarded as one to the person but ... is regarded as . . . arising out of contract."); Grabow v Bergeth, 59 ND 214, 229 NW 282, 287 (1930) (holding that mere cause of action for fraud does not arise out of a violation of a right of property and is not assignable); Investors Title Insurance Co v Herzig, 101 NC App 127, 398 SE2d 659, 662 (1990) (holding that claim for conspiracy to commit fraud arising out of contract interests is assignable); Trust Company of Norfolk $v$ Fletcher, 152 Va 868, 148 SE 785, 787 (1929) (noting that the test for the survivability of a tort claim is whether it arises out of a property right); Mayer v Rankin, 91 Utah 193, 63 P2d 611, 616-17 (1936) (holding that a fraud claim is assignable where attached to property); Kane $v$ Klos, 50 Wash $2 \mathrm{~d} 778,314$ P2d 672,677 (1957) (holding right to recover money fraudulently obtained assignable as property claim).

4. Cases and statutes suggesting that assignability depends on nature of claim; no cases on fraud claims, but assignability of tort claims in general turns on personal/property distinction.

Harleysuille Mutual Insurance Co v Lea, 2 Ariz App 538, 410 P2d 495, 498-99 (1966) (holding that although personal injury claims survive under the statute, they are not assignable); Southern Farm Bureau Casualty Insurance Co $v$ Wright Oil Co, 248 Ark 803, 454 SW2d 69, 71 (1970) (holding that unliquidated tort claims are not assignable); Austin $v$ Michiels, 6 Hawaii 595, 595 (1885) ("[N]o action of which the gist consists of injury to the feelings or in which injury or insult is an aggravation, can be assigned, voluntarily or by operation of law."); Cuson v Maryland Casualty Co, 735 F Supp 966, 969-70 (D Hawaii 1990) (holding that rule against assigning personal injury claims is still the law in Hawaii); Picadilly, Inc $v$ Raikos, 582 NE2d 338, 340-41 (Ind 1991) (rejecting the survival/assignable equivalency and noting rule that personal injury claims cannot be assigned); State Farm Mutual Automobile Insurance Co v Roark, 517 SW2d 737, 739 (Ky App 1974) (holding that unliquidated claims for personal injuries are not assignable); Gilboy $v$ American Tobacco Co, 540 S2d 391, 393 (La App 1989) (holding that personal injury claims are personal to the victim and not assignable); Metropolitan Insurance Co $v$ Day, $119 \mathrm{Me} 380,111 \mathrm{~A} \mathrm{429,} 429$ (1920) (holding that personal injury and property claims are distinguishable for purposes of assignment); Allstate Insurance Co $v$ Reitler, 192 Mont 351, 628 P2d 667, 670 (1981) ("Montana has long opposed the assignment of personal injury claims."); Saloshin v Houle, $85 \mathrm{NH}$ 126, $155 \mathrm{~A} \mathrm{47,} 49$ (1931) (holding that cause of action in tort, if not terminable by death and if arising out of property interests, is assignable); Young $v$ New Mexico Broadcasting Co, 60 NM 475, 292 P2d 776, 779 (1956) ("Generally, a right of action for purely personal tort is not assignable before judgment."), modified on other grounds, 81 NM 608, 471 P2d 178 (1970); Sensenig v Pennsylvania Rail Co, $229 \mathrm{~Pa} \mathrm{168,78} \mathrm{A} \mathrm{91,} \mathrm{91-92} \mathrm{(1910)} \mathrm{(holding} \mathrm{that} \mathrm{a} \mathrm{right} \mathrm{of} \mathrm{action} \mathrm{for} \mathrm{personal} \mathrm{tort} \mathrm{is} \mathrm{not} \mathrm{as-}$ signable); Hedlund Manufacturing Co, Inc v Weiser, Stapler \& Spivak, 517 Pa 522, 539 A2d 357, 358-59 (1988) (allowing assignment of legal malpractice claim on finding that it arises from pecuniary interests); Hospital Service Corporation of Rhode Island v Pennsylvania Insurance Co, 101 RI 708, 227 A2d 105, 109 (1967) (holding that assignment of a personal injury claim is not permitted); Can Do, Inc Pension and Profit Sharing $v$ Manier, Herod, Hollabaugh \& Smith, 922 SW2d 865, 867-68 (Tenn 1996) (rejecting practice of equating survival and assignability; holding that some choses in action that survive are not assignable and turning to public policy to decide assignability of legal malpractice action). 
5. Fraud claims are probably assignable; no cases or statutes on fraud claims, but assignability of claims depends on survival and survival statute appears to provide for survival of claims for fraud and deceit.

Alaska Stat § 09.55.570 (1996) (declaring that all actions except defamation survive); Andersen $v$ Edwards, 625 P2d 282, 290 (Alaska 1981) (holding that a cause of action may be assigned as long as it survives); 10 Del Code Ann $\$ 3701$ (1995) (declaring that all actions except an enumerated few survive); Garford Motor Truck Co v Buckson, 34 Del 103, 143 A 410, 411 (Del Super Ct 1927) (holding that assignability turns on survivability); Ohio Rev Code Ann $\S 2305.21$ (Baldwin 1994) (providing for survival of claims for deceit and fraud); Grant $v$ The Administrator of James C. Ludlow, 8 Ohio St 1, $37-38$ (1857) (holding that all rights of action that survive are assignable); Or Rev Stat $\$ 115.305$ (1995) (providing for survival of all causes of action); Sperry $v$ Stennick, 64 Or 96, 129 P 130, 132 33 (1913) (linking survivability and assignability, and holding that while one may not assign an action for fraud, one may assign a contractual claim that is predicated on a showing of fraud). But see Johnson v Bergstrom, 284 Or 343, 587 P2d 71, 73 (1978) (treating as an open question whether survivability should be the test for assignability); Doremus $v$ Atlantic Coast Line Railroad Co, 242 SC 123, 130 SE2d 370, 379 (1963) (holding that survival statute authorizes survival of all causes of action and assignability turns on survivability). 